\title{
Effect of Peaches, Pears and Green Tea on Plasma Lipids Profile and Antioxidant Content in Rats Fed High Sucrose Diet
}

\author{
Nada A. Al Zunaidy' ${ }^{1}$, Noorah S. Al-Sowayann ${ }^{2}$, Hassan M. Mousa ${ }^{3}$ \\ ${ }^{1}$ Department of nutrition, College of Design and Home Economic, Qassim University, Qassim, Saudi Arabia \\ ${ }^{2}$ Department of Biology, Faculty of Science, Buraidah, Qassim University, Qassim, Saudi Arabia \\ ${ }^{3}$ Department of Food Science and Human Nutrition, College of Agriculture \&Veterinary Medicine, Qassim \\ University, Qassim, Saudi Arabia \\ Email: ${ }^{*}$ knaaj1@yahoo.com
}

Received 11 June 2015; accepted 21 July 2015; published 24 July 2015

Copyright (C) 2015 by authors and Scientific Research Publishing Inc.

This work is licensed under the Creative Commons Attribution International License (CC BY).

http://creativecommons.org/licenses/by/4.0/

cc) (i) Open Access

\section{Abstract}

The beneficial effects of feeding syrup of peaches and pears (peel and pulp) \& green tea on the restoration of the changes produced by feeding high sucrose diet on plasma lipid profile, plasma antioxidant activity, and antioxidant enzymes in red blood cells (RBC) hemolysate were studied. High sucrose diet induced hyperlipidemia as manifested by significant $(P \leq 0.05)$ increases in the levels of cholesterol, triglycerides (TG) and low density lipoproteins (LDL) in plasma from 103.33 $\pm 1.8,61.17 \pm 0.48$ and $26.6 \pm 5.01 \mathrm{mg} / \mathrm{dl}$ to $136.67 \pm 2.2,81.3 \pm 1.5$ and $64.6 \pm 6.5 \mathrm{mg} / \mathrm{dl}$ respectively. The high density lipoproteins (HDL) level was not significantly affected. TG levels in heart muscles increased significantly $P \leq 0.05$ from the level of $194.14 \pm 4.35 \mu \mathrm{g} / \mathrm{g}$ in the negative control to $269.72 \pm 5.39 \mu \mathrm{g} / \mathrm{g}$. Administration of fruits syrup and green tea resulted in a significant variable reduction in the elevated levels of cholesterol, TG and LDL and TG in the heart. Administration of sucrose resulted also in elevation of Malondialdehyde (MDA) in plasma from 5.06 \pm 0.18 in the negative control to $14.81 \pm 0.48 \mu \mathrm{mol} / \mathrm{L}$ in the positive control. This was also accompanied by reduction in the activities of supper oxide dismutase (SOD), glutathione peroxidase (GSH-Px), catalase (CAT) and a decrease in the concentration of reduced glutathione (GSH) in plasma, indicating lipid peroxidation. The activities of SOD, GSH-Px, CAT in the negative control were $8.96 \pm$ $0.19,315.67 \pm 5.86,209 \pm 2.18 \mathrm{U} / \mathrm{gHb}$ respectively and were reduced significantly in the positive control to $4.7 \pm 0.2,273.83 \pm 7.85,207 \pm 2.53 \mathrm{U} / \mathrm{g} \mathrm{Hb}$. There was a significant decrease in the level of total antioxidant status (TAS) in plasma from $1.45 \pm 0.09$ to $0.88 \pm 0.09 \mathrm{nmol} / \mathrm{L}$. However, no statistically significant changes were noticed in the concentrations of plasma total proteins and albumin. Intake of syrup of peaches and pears (peel and pulp) \& green tea increased the level of TAS and GSH and decreased the level of LDL. The treatment also decreased significantly $(P \leq 0.05)$

${ }^{*}$ Corresponding author.

How to cite this paper: Al Zunaidy, N.A., Al-Sowayan, N.S. and Mousa, H.M. (2015) Effect of Peaches, Pears and Green Tea on Plasma Lipids Profile and Antioxidant Content in Rats Fed High Sucrose Diet. Food and Nutrition Sciences, 6, 893-905.

http://dx.doi.org/10.4236/fns.2015.610094 
the levels of plasma cholesterol, TG and heart TG levels. The activities of SOD and GSH-Px were increased following the treatment. It can be concluded that syrup of peaches and pears (peel and pulp) \& green tea modulate lipid metabolism and enhance antioxidant status and in this respect green tea produced the best effect followed by peels of pears and peaches. The beneficial effect produced by fruits syrup and green tea may be due to their contents of phytochemicals.

\title{
Keywords
}

\author{
Sucrose, Lipid Profile, Lipid Peroxidation, Green Tea, Fruits
}

\section{Introduction}

The health benefits of fruits and vegetables consumption have been confirmed for decades [1]-[3]. Consumption of fruits and vegetables reduce risk of diseases such as Type II diabetes, cardiovascular diseases (CVD), certain cancers, kidney stones and obesity [4]-[6]. Fruits and vegetables are relatively low in calories but rich in certain nutrients and fiber [7]-[9]. In Countries like North America, cardiovascular disease is a leading cause of death and may be due to factors such as tobacco smoking, alcohol consumption, salty food and high fat diet. Epidemiological studies have established a negative relationship between consumption of fruits, vegetables and cardiovascular diseases [10]-[13]. In Saudi Arabia and other Middle East countries CVD is a widespread problem. It is the leading cause of mortality and in most hospitals in this country beds are occupied by patients suffering from CVD [14]-[16]. Obesity is highly prevalent in Saudi Arabia. In a Population based study, Al-Nuaim et al. [17], found that obesity in Saudi Arabia was $15 \%$ and $24 \%$ for male and female subjects over the age of 15 years, respectively. Serum lipids and lipoproteins are important indicators and play important roles in the development of CVD [18]. Hypercholesterolemia, high levels of serum triglycerides (TG), high levels of serum low-density lipoprotein cholesterol (LDL) represent increased risk of CVD [19] [20] and are usually used as indicators. Consumption of fruits and vegetable (FV) has been associated with low risk mortality from non-communicable diseases such as hypertension, cardiovascular diseases, stroke, diabetes and coronary heart diseases [4] [6]. Several constituents of FV such as antioxidants, vitamins, minerals and other phytochemical compounds may be involved in the protection by mechanisms such as reducing oxidative stress and inflammatory markers and improving homeostasis regulation, lowering blood pressure and increasing insulin sensitivity [5]. Epidemiological studies have linked tea (Camellia sinensis) consumption with prevention of heart diseases [21]: obesity and diabetes [22], and many other disorders. Green tea has gained attention in research studies due to its contents of a group of flavonoids specially catechins that include epicatechin (EC), epicatechin gallate (ECG), epigallocatechin (EGC) [23] and epigallocatechingallate (EGCG) [24]. These catechins have strong antioxidant properties and free radical scavenging activity, antimicrobial and antiviral agent [25] [26]. Many studies have shown that green and black teas have anticholesterolemic effect [27] [28] modulation of plasma lipid profiles [29] and enhancing vasodilatation [30], increasing fatty acid oxidation and insulin sensitivity. Pears (Pyruscommunis) gained popularity among consumers due to its good taste and high digestibility. Pears have high soluble phenolic content and high antioxidant activity particularly in the peel extracts [31]. The phenolic compounds in pears are chlorogenic acid, p-coumaroylquinic acid, p-coumaroylmalic acid, dicafeolquinic acid, catechin, epicatechin proanthocyanidins, quercetin derivatives, isorhamnetin, and kaemferol [32] [33]. In the other hand peaches (Prinuspersica) are appreciated by consumers [34]. Peaches possess beneficial properties for human and have high contents of Phenolic compounds, flavonoids, vitamin $\mathrm{C}$ and anthocyanins which may act as antioxidants. [35]. Sucrose is naturally found in many foods and is the most common sweetener when added to the human diet. There is high concern regarding derivation of high proportion of the daily energy from simple sugar especially in the modern diet. It was found that this will increase the risk of excess weight gain, dental caries, type 2 diabetes and cardiovascular diseases [36]. Sucrose rich diet has been proven to be lipogenic and elevate the level of triglycerides (TG) in the liver and heart. Continuous consumption of sucrose rich diet (SRD) resulted in hypertriglyceridemia and hyperglycemia [37]-[39]. The present study was undertaken to investigate the effect of high sucrose diet on modulation of lipid metabolism on rats and attempted to elucidate the effect of peaches, pears and green tea on plasma lipid profile and plasma antioxidant activity in rats fed high sucrose diet. 


\section{Materials and Methods}

\subsection{Animal Model and Diet}

Male adult Wistar rats five weeks old weighing between 150 - $200 \mathrm{~g}$ were used in the present study. All experiments and study was approved by the Institutional Animal Ethics Committee (IAEC) of Qassim University, Saudi Arabia, regulated by the Committee for the Purpose of the Control and the Supervision of Experiments on Animals (CPCSEA). The animals were housed in polyacrylate cages $(38 \times 23 \times 10 \mathrm{~cm})$ with not more than four rats per cage. They were housed in an air-conditioned room and kept in standard laboratory conditions under standard light and dark cycles (12 h light and $12 \mathrm{~h}$ dark) and maintained at an ambient temperature of $25^{\circ} \mathrm{C} \pm$ $2^{\circ} \mathrm{C}$. The animals were fed standard pellet diet) and water ad libitum. The composition of the rat chow is shown in Table 1.

Control-diet group was provided with basal diet while the second group (positive control) consumed sucroserich diet only. The sucrose rich diet was prepared from $650 \mathrm{~g}$ of the basal diet $+350 \mathrm{~g}$ of commercial sucrose obtained from supermarkets. Peels and pulp of pears and peaches were collected and dried at $45^{\circ} \mathrm{C}$ till reached constant weight. Aqueous fruits and green tea extracts were prepared (10\%) every day and supplied twice daily in drinking water for the green tea, peaches and pears groups. The sucrose-rich diets are supposed to induce hypertriglyceridemia and hypercholesterolemia.

\subsection{Experiment Design}

The animals were divided into 7 equal groups, ten each, and they were subjected to such diet to induce hyperlipidemia, as follows:

1) 1st group was Negative Control (normal animals), the animals were fed standard pellet diet without any additions.

2) 2nd group was the positive Control, which was fed with a high sucrose diet.

3) 3rd group was fed with the same high sucrose diet with pear's pulp extract.

4) 4th group was fed with the same high sucrose diet and pear's peel extract.

5) 5th group was fed with the same high sucrose diet and extract of the pulp of the peach.

6) 6th group was fed with the same high sucrose diet and extract of peel of peach.

7) 7th group was fed with the same high sucrose diet with green tea extract.

Acclimatization period continued for 7 days. The experimental period continued for 6 weeks.

\subsection{Blood Collection}

Blood was collected from the retro-orbital plexus under mild ether anesthesia in heparinized centrifuge tubes Table 1. Composition of the basal diet (control-).

\begin{tabular}{cc}
\hline Ingredient & Content \\
\hline Crude protein & $20 \%$ \\
Crude fat & $4 \%$ \\
Crude fibers & $3.5 \%$ \\
Soya bean & $25 \%-30 \%$ \\
Wheat bran & $8 \%-10 \%$ \\
Soya bean & $25 \%-30 \%$ \\
Barseem & $4 \%$ \\
Ash & $6 \%$ \\
Salts & $0.5 \%$ \\
Calcium & $1 \%$ \\
Phosphorus & $0.6 \%$ \\
Vegetable oil & $1.5 \%$ \\
\hline
\end{tabular}


and then centrifuge at $3000 \mathrm{rpm}$ for $30 \mathrm{~min}$. The resultant clear supernatant was collected and stored at $-20^{\circ} \mathrm{C}$. Red blood cells were rinsed three times with isotonic solution of $\mathrm{NaCl}(0.9 \%)$ and centrifuged for $10 \mathrm{~min}$ at $3000 \mathrm{~g}$. The supernatant was discarded and the red blood cells were processed. Sedimented cells were hemolysed with 9- fold volume distilled water to prepare $10 \%(\mathrm{v} / \mathrm{v})$ hemolysate. Hemoglobin $(\mathrm{Hb})$ concentration, packed cell volume (PCV), red blood cells (RBC) were determined by the Abbott Cell Dyn ${ }^{\circledR} 3500$ (Abbott Diagnostic Division, California (USA).

\subsection{Biochemical Assays}

The collected plasma was used to evaluate lipid peroxides. Malondialdehyde (MDA) was determined according to the method of Lukaszewicz-Hussain \& Moniuszko-Jakoniuk, [40]. Reduced glutathione was determined by commercial kit STA-312: OxiSelect ${ }^{\mathrm{TM}}$ (Total Glutathione (GSSG/GSH) Assay KitTrevigen, Inc.8405 Helgerman Ct. Gaithersburg, MD 20877. Superoxide dismutase (SOD) was assayed in RBCs hemolysate using (STA340: OxiSelect ${ }^{\mathrm{TM}}$ Superoxide Dismutase Activity Assay Kit, Trevigen, Inc. 8405 Helgerman Ct. Gaithersburg, MD 20877). Glutathione peroxidase activity in erythrocyte hemolysate was measured using Randox kits (ref. BS 505.), Catalase Activity in erythrocyte hemolysate was determined by Assay Kit, Colorimetric Catalog Number STA-341. Trevigen, Inc. 8405 Helgerman Ct. Gaithersburg, MD 20877. Activity of all three enzymes was expressed in units per mg of $\mathrm{Hb}$.

The activities of aspartate aminotransferase (AST), alanine aminotransferase; (ALT) were determined by the method of Reitmanand Frankel [41] and the concentrations of total proteins by the method of Bradford [42] and albumin was determined using standard diagnostic kits (Reckon Diagnostic Ltd., India).

Total cholesterol (TC) was determined according to the method of Tietz [43], Triglyceride (TG) by the method of Davidson and Henry [44], High density lipoproteins (HDL-C) were determined by the method of Grillo et al. [45], using standard diagnostic kits (Reckon Diagnostic Ltd., India). Low density lipoprotein (LDL-c) was determined using Fridwald's formula.

Total antioxidant status (TAS) weredetermined using a standard kit (Span Diagnostic Pvt Ltd., India). From the sample of heart tissue, homogenate lipids were extracted using the method of Folch et al. [46]. To a known volume of tissue homogenate, $10 \mathrm{ml}$ of chloroform:methanol mixture (2:1) was added and mixed well for 30 min using a mechanical shaker and filtered through Whatman filter paper (No. 42) into a separating funnel. The filtrate was mixed with $0.2 \mathrm{ml}$ of physiological saline, and the mixture was kept overnight undisturbed. The lower phase containing lipid was drained off into a pre-weighted beaker. The upper phase was re-extracted with more of chloroform-methanol mixture and the extract was pooled and evaporated under vacuum at room temperature. The lipid extract was re-dissolved in $3 \mathrm{ml}$ of chloroform methanol (2:1) mixture, and these collected aliquots were used to estimate the Triglyceride (TG) and were determined using standard diagnostic kits (Reckon Diagnostic Ltd., India).

\subsection{Histological Examination}

After decapitation, the heart was rapidly dissected out, washed immediately with saline, Two samples of heart tissues were taken from all groups and quickly labeled. One sample of heart tissues was stored deep-frozen $\left(-20^{\circ} \mathrm{C}\right)$ until used for assays of triglycerides. Other samples were fixed in $10 \%$ buffered formalin. Hearts, which were stored in $10 \%$ formalin, were embedded in paraffin; sections cut at $5 \mu \mathrm{m}$ and stained with haematoxylin and eosin. Sections of the heart were analysed microscopically (Olympus BX10) for histological changes.

\subsection{Statistical Analysis}

Results are presented as mean \pm SEM. Two-way analysis of variance (ANOVA) followed by Bonferroni multiple comparisons using a computer-based fitting program (Prism, GraphPad). Differences were considered to be statistically significant when $\mathrm{P}<0.05$.

\section{Results}

\subsection{Body Weight}

Increase in body weight at the end of the experimental period in the different treatment groups are presented in 
Figure 1. There was no statistically significant difference between the groups.

\subsection{Levels of Triglycerides in Heart Tissues}

Levels of triglycerides in heart tissues are shown in Table 2. Levels in the negative control, positive control, pulp of peaches, peel of peaches, pulp of pears, peel of pears and green tea are 194.14 $\pm 4.35,269.72 \pm 5.39$, $201.5 \pm 2.95,187.43 \pm 3.63,210.37 \pm 3.14,166.52 \pm 32.77,164.97 \pm 3.36 \mu \mathrm{g} / \mathrm{g}$ respectively. The level was statistically $(\mathrm{P} \leq 0.05)$ higher in the positive control when compared with all other groups. The lowest level in all groups was the level in the group that received green tea followed by the group that received peel of pears. As can be seen that the pulp of both pears and peaches scored higher non-significant levels of heart triglycerides when compared with the negative control.

\subsection{Levels of Cholesterol, LDL, HDL, Triglycerides, Albumin and Total Proteins in Plasma Cholesterol}

Levels of cholesterol, LDL, HDL, triglycerides, albumin and total proteins are presented in Table 3. The level of cholesterol in the negative control group was $103.33 \pm 1.8 \mathrm{mg} / \mathrm{dl}$ that level was found to increase significantly $\mathrm{P} \leq 0.05$ to $136.67 \pm 2.2 \mathrm{mg} / \mathrm{dl}$ in the positive control group. Different treatments lowered significantly $(\mathrm{P} \leq 0.05)$ the level of cholesterol when compared with the positive control group. The best lowering of plasma cholesterol was recorded in the group that received green tea $(70.15 \pm 1.14 \mathrm{mg} / \mathrm{dl})$ followed by the group that received peel of peaches and then peel of pears (78.88 \pm 2.6 and $99.74 \pm 0.85 \mathrm{mg} / \mathrm{dl}$ respectively).

\subsection{Triglycerides}

The level of triglycerides in the plasma is shown in Table 3. The level's in the negative control, positive control,

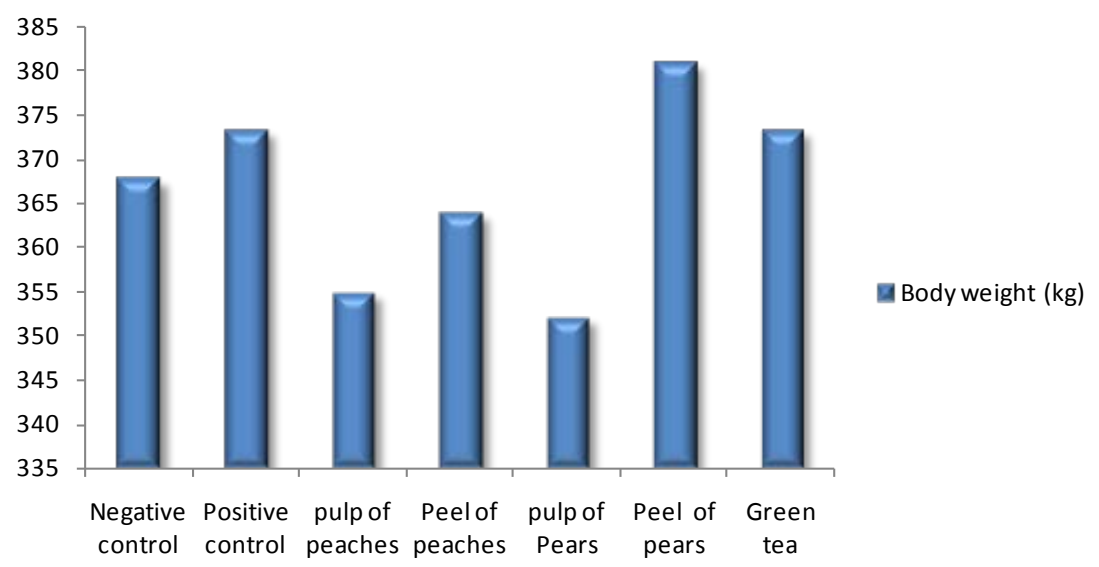

Figure 1. Body weight changes in the different groups at the end of the experimental period.

Table 2. Triglyceride levels in heart muscles of the different groups.

\begin{tabular}{cc}
\hline Groups & Heart TG $(\boldsymbol{\mu g} / \mathbf{g})$ \\
\hline Negative control & $194.14 \pm 4.35^{\mathbf{c b}}$ \\
Positive control & $269.72 \pm 5.39^{\mathbf{a}}$ \\
pulp of peaches & $201.5 \pm 2.95^{\mathbf{c b}}$ \\
Peel of peaches & $187.43 \pm 3.63^{\mathbf{c b}}$ \\
pulp of Pears & $210.37 \pm 3.14^{\mathbf{b}}$ \\
Peel of pears & $166.52 \pm 32.77^{\mathbf{c}}$ \\
Green tea & $164.97 \pm 3.36^{\mathbf{c}}$ \\
\hline
\end{tabular}

Means on the same column with different superscripts are significantly different at $\mathrm{P} \leq 0.05$. 
Table 3. Levels of cholesterol, LDL, HDL, triglycerides, albumin and total proteins in plasma.

\begin{tabular}{ccccccc}
\hline Groups & $\begin{array}{c}\text { Cholesterol } \\
\mathbf{m g} / \mathbf{1 0 0} \mathbf{m}\end{array}$ & $\begin{array}{c}\text { LDL } \\
\mathbf{m g} / \mathbf{1 0 0 m l}\end{array}$ & $\begin{array}{c}\text { HDL } \\
\mathbf{m g} / \mathbf{1 0 0} \mathbf{m}\end{array}$ & $\begin{array}{c}\text { TG } \\
\mathbf{m g} / \mathbf{1 0 0} \mathbf{m l}\end{array}$ & Albumin g/100ml Protein g/100ml \\
\hline Negative control & $103.33 \pm 1.8^{\mathbf{c b}}$ & $26.6 \pm 5.01^{\mathbf{b}}$ & $60.5 \pm 0.43^{\mathbf{a}}$ & $61.17 \pm 0.48^{\mathbf{d}}$ & $4.08 \pm 0.06^{\mathbf{a}}$ & $7.37 \pm 0.13^{\mathbf{a}}$ \\
Positive control & $136.67 \pm 2.2^{\mathbf{a}}$ & $64.6 \pm 6.5^{\mathbf{a}}$ & $61.0 \pm 0.82^{\mathbf{a}}$ & $81.3 \pm 1.5^{\mathbf{a}}$ & $4.13 \pm 0.17^{\mathbf{a}}$ & $7.43 \pm 0.13^{\mathbf{a}}$ \\
pulp of peaches & $101.63 \pm 2.5^{\mathbf{c}}$ & $27.6 \pm 2.3^{\mathbf{b}}$ & $60.7 \pm 0.88^{\mathbf{a}}$ & $67.48 \pm 0.54^{\mathbf{b}}$ & $4.03 \pm 0.08^{\mathbf{a}}$ & $7.2 \pm 0.12^{\mathbf{a}}$ \\
Peel of peaches & $78.88 \pm 2.6^{\mathbf{d}}$ & $8.2 \pm 1.5^{\mathbf{c}}$ & $60.7 \pm 0.88^{\mathbf{a}}$ & $63.47 \pm 0.8^{\mathbf{d}}$ & $4.1 \pm 0.12^{\mathbf{a}}$ & $7.25 \pm 0.09^{\mathbf{a}}$ \\
pulp of Pears & $108.48 \pm 1.06^{\mathbf{b}}$ & $36.4 \pm 3.3^{\mathbf{b}}$ & $60.8 \pm 0.6^{\mathbf{a}}$ & $71.47 \pm 0.88^{\mathbf{b}}$ & $3.73 \pm 0.22^{\mathbf{a}}$ & $7.08 \pm 0.05^{\mathbf{a}}$ \\
Peel of pears & $99.74 \pm 0.85^{\mathbf{c}}$ & $26.04 \pm 0.62^{\mathbf{b}}$ & $60.4 \pm 0.42^{\mathbf{a}}$ & $66.92 \pm 0.81^{\mathbf{c}}$ & $3.95 \pm 0.06^{\mathbf{a}}$ & $7.2 \pm 0.25^{\mathbf{a}}$ \\
Green tea & $70.15 \pm 1.14^{\mathbf{e}}$ & $4.6 \pm 0.74^{\mathbf{c}}$ & $62.0 \pm 0.45^{\mathbf{a}}$ & $50.8 \pm 0.65^{\mathbf{e}}$ & $4.09 \pm 0.08^{\mathbf{a}}$ & $7.2 \pm 0.11^{\mathbf{a}}$ \\
\hline
\end{tabular}

Means on the same column with different superscripts are significantly different at $\mathrm{P} \leq 0.05$.

pulp of peaches, peel of peaches , pulp of pears, peel of pears and green tea are $61.17 \pm 0.48,81.3 \pm 1.5,67.48 \pm$ $0.54,63.47 \pm 0.8,71.47 \pm 0.88,66.92 \pm 0.81,50.8 \pm 0.65 \mathrm{mg} / \mathrm{dl}$ respectively. All treatments decreased significantly $(\mathrm{P} \leq 0.05)$ the levels of triglycerides when compared with the positive control that received sucrose without any treatment. The best decrease was reported in the group that received green tea.

\subsection{HDL Levels}

The level of HDL in the negative control, positive control ,pulp of peaches, peel of peaches, pulp of pears, peel of pears and green tea are $60.5 \pm 0.43,61.0 \pm 0.82,60.7 \pm 0.88,60.8 \pm 0.6,60.4 \pm 0.42,62.0 \pm 0.45 \mathrm{mg} / \mathrm{dl} \mathrm{re}-$ spectively. There were no statistically significant differences between different groups when compared with the positive control group despite a non-significant increase in the level of HDL in the group that received green tea.

\subsection{LDL Levels}

The level of LDL in the negative control was $26.6 \pm 5.01 \mathrm{mg} / \mathrm{dl}$ and in the positive control it increased significantly to $64.6 \pm 6.5 \mathrm{mg} / \mathrm{dl}$. All treatments resulted in significant decreases in the levels of LDL, with green tea producing the best lowering effect followed by peel of peaches and then peels of pears.

\subsection{Total Plasma Proteins and Albumin}

Ascan be depicted from Table 3, different treatments resulted in no significant differences in both the levels of total proteins and albumins.

\subsection{Malondialdehyde (MDA), Reduced Glutathione, TAS in Plasma and Antioxidant Enzymes in RBCS Hemolysatein Rats}

Levels of MDA, reduced glutathione, antioxidant enzymes and total antioxidant status in rats are shown in Table 4.

\subsection{MDA Levels}

The level of MDA in negative control group was $5.06 \pm 0.18 \mu \mathrm{mol} / \mathrm{L}$ that increased $(\mathrm{P} \leq 0.05)$ in the positive control group $(14.81 \pm 0.48 \mu \mathrm{mol} / \mathrm{L})$. All treatments produced significant decrease in the levels of MDA. The best reduction as presented in Table 4 is achieved in the group that received green tea followed by peel of peaches, pulp of peaches. Significant reduction was also produced by peel and pulp of pears.

\subsection{Total Antioxidant Status (TAS)}

The levels of TAS in the plasma of rats in the different groups is shown in Table 5. The level of TAS in the negative and positive controls are $1.45 \pm 0.09 \& 0.88 \pm 0.09 \mathrm{nmol} / \mathrm{L}$ respectively. Treatment with pulp of peaches, peel of peaches, pulp of pears, peel of pears and green tea are $2.74 \pm 0.18,3.76 \pm 0.27,2.87 \pm 0.22$, 
N. A. Al Zunaidy et al.

Table 4. Lipid peroxides, reduced glutathione, antioxidant enzymes and total antioxidant status in RBCS hemolysate in rats.

\begin{tabular}{|c|c|c|c|c|c|c|}
\hline Groups & $\begin{array}{c}\text { MDA } \\
(\mu \mathrm{mol} / \mathrm{L})\end{array}$ & $\begin{array}{c}\text { SOD } \\
\text { (U/g Hb) }\end{array}$ & $\begin{array}{l}\text { GSH-Px } \\
\text { (U/g Hb) }\end{array}$ & $\begin{array}{c}\text { CAT } \\
\text { (U/g Hb) }\end{array}$ & $\begin{array}{l}\text { GSH (reduced) } \\
(\mathrm{mmol} / \mathrm{L})\end{array}$ & TAS (nmol/L) \\
\hline Negative control & $5.06 \pm 0.18^{c}$ & $8.96 \pm 0.19^{\mathrm{e}}$ & $315.67 \pm 5.86^{d}$ & $209.17 \pm 2.18^{\mathrm{cb}}$ & $9.03 \pm 0.12^{\mathrm{e}}$ & $1.45 \pm 0.09^{\mathrm{e}}$ \\
\hline Positive control & $14.81 \pm 0.48^{\mathrm{a}}$ & $4.7 \pm 0.2^{f}$ & $273.83 \pm 7.85^{\mathrm{e}}$ & $207.0 \pm 2.53^{c}$ & $7.45 \pm 0.36^{f}$ & $0.88 \pm 0.09^{f}$ \\
\hline pulp of peaches & $6.65 \pm 0.33^{b}$ & $11.65 \pm 0.37^{\mathrm{c}}$ & $341.5 \pm 15.14^{\mathrm{dc}}$ & $215.0 \pm 2.71^{\mathrm{cb}}$ & $10.39 \pm 0.24^{\mathrm{d}}$ & $2.74 \pm 0.18^{\mathrm{d}}$ \\
\hline Peel of peaches & $5.34 \pm 0.29^{c}$ & $14.7 \pm 0.44^{\mathbf{b}}$ & $406.83 \pm 3.91^{\mathbf{b}}$ & $216.17 \pm 3.26^{\mathbf{b}}$ & $12.45 \pm 0.48^{c}$ & $3.76 \pm 0.27^{c}$ \\
\hline pulp of Pears & $7.01 \pm 0.18^{\mathrm{b}}$ & $10.2 \pm 0.34^{\mathrm{d}}$ & $314.83 \pm 15.88^{d}$ & $211.83 \pm 2.17^{\mathrm{cb}}$ & $10.05 \pm 0.17^{\mathrm{d}}$ & $2.87 \pm 0.22^{\mathrm{d}}$ \\
\hline Peel of pears & $6.79 \pm 0.18^{b}$ & $12.58 \pm 0.37^{\mathrm{c}}$ & $362.0 \pm 15.18^{c}$ & $210.33 \pm 2.89^{\mathrm{cb}}$ & $13.96 \pm 0.32^{\mathbf{b}}$ & $13.58 \pm 10.28^{a}$ \\
\hline Green tea & $2.82 \pm 0.22^{\mathrm{d}}$ & $22.55 \pm 0.61^{\mathrm{a}}$ & $460.75 \pm 6.39^{\mathrm{a}}$ & $228.75 \pm 3.66^{\mathrm{a}}$ & $17.14 \pm 0.41^{\mathrm{a}}$ & $7.02 \pm 0.34^{\mathbf{b}}$ \\
\hline
\end{tabular}

Means on the same column with different superscripts are significantly different at $\mathrm{P} \leq 0.05$.

Table 5. Activities of liver enzymes in plasma of different groups.

\begin{tabular}{ccc}
\hline Groups & ALT (IU/L) & AST (IU/L) \\
\hline Negative control & $28.9 \pm 1.4^{\mathrm{e}}$ & $22.5 \pm 3.7^{\mathrm{e}}$ \\
Positive control & $77.6 \pm 3.9^{\mathrm{a}}$ & $77.5 \pm 4.4^{\mathrm{a}}$ \\
pulp of peaches & $65.9 \pm 2.2^{\mathbf{b c}}$ & $38.7 \pm 1.2^{\mathrm{c}}$ \\
Peel of peaches & $56.8 \pm 2.9^{\mathbf{d}}$ & $32.0 \pm 1.9^{\mathbf{c d}}$ \\
pulp of Pears & $71.2 \pm 3.3^{\mathbf{b a}}$ & $48.6 \pm 2.1^{\mathbf{b}}$ \\
Peel of pears & $62.4 \pm 2.2^{\mathrm{dc}}$ & $39.0 \pm 0.79^{\mathbf{c}}$ \\
Green tea & $27.5 \pm 1.3^{\mathbf{e}}$ & $25.6 \pm 1.13^{\mathrm{de}}$ \\
\hline
\end{tabular}

Means on the same column with different superscripts are significantly different at $\mathrm{P} \leq 0.05$.

$13.58 \pm 10.28,7.02 \pm 0.34 \mathrm{nmol} / \mathrm{L}$. All of the treatments increased the level of TAS significantly, however, the highest increase was produced by the peel of pears followed by the group of green tea.

\subsection{Reduced Glutathione (GSH)}

The levels of reduced glutathione in the negative and positive control groups are $9.03 \pm 0.12$ and $7.45 \pm 0.36$ $\mathrm{mmol} / \mathrm{L}$ respectively. Different treatments increased the level of GSH when compared with the positive control as presented in Table 4. The best increase was produced by green tea followed by peel of pears and then peel of peaches.

\subsection{Antioxidant Enzymes}

Activities of the antioxidant enzymes, supper oxide dismutase (SOD), Glutathione peroxidase (GSHx) and Catalase in the RBCS hemolysate of rats of the different groups are presented in Table 4.

\subsection{Activities of SOD}

Activities of SOD in the negative and positive control groups are $8.96 \pm 0.19$ and $4.7 \pm 0.2 \mathrm{U} / \mathrm{g} \mathrm{Hb}$ respectively. Different treatments produced increase in the activities of SOD. Green tea resulted in the highest significant increase $(\mathrm{P} \leq 0.05)$ followed by peel of peaches group and then peel of pears.

\subsection{Activities of GSHx}

Activities of GSHx in the negative and positive control groups are $315.67 \pm 5.86$ and $273.83 \pm 7.85 \mathrm{U} / \mathrm{g}$ Hb respectively. Administration of fruits and tea resulted in significant increases in the activities of the enzyme. The 
highest increase was in the green tea group followed by the group that received peel of peaches and then the group treated with peel of pears.

\subsection{Activities of Catalase}

Activities of Catalase in the negative and positive control groups are $209.17 \pm 2.18$ and $207.0 \pm 2.53 \mathrm{U} / \mathrm{g} \mathrm{Hb}$. There was no significant difference in the activities of the enzyme in the two groups. However, only administration of green tea resulted in a significant increase in the activity of the enzyme (228.75 $\pm 3.66 \mathrm{U} / \mathrm{g} \mathrm{Hb})$.

\subsection{Activities of Liver Enzymes}

The activities of Alanine transaminase (ALT) and Aspartate aminotransferase (AST) were measured in the sera of different groups as presented in Table 5 .

\subsection{The Activities of Alanine Transaminase (ALT)}

The activities of the enzyme in the negative and positive control were $28.9 \pm 1.4$ and $77.6 \pm 3.9$ IU/L respectively. There was a significant increase in the activity of the positive control when compared with the normal negative control rats. Administration of green tea, peaches and pears resulted in lowering of the elevated enzyme activity with best lowering with green tea. However, lowering of enzyme activity produced by pulp of pears was not significant.

\subsection{The Activities of Aspartate Aminotransferase (AST)}

The activities of the enzyme in the negative and positive control were $22.5 \pm 3.7$ and $77.5 \pm 4.4$ IU/L respectively. Administration of green tea, peaches and pears resulted in reduction of the activities of AST, again the best reduction was produced by green tea.

\subsection{Histopathological Changes}

The histopathological changes are presented in Figure 2 and explained in Table 6.

\section{Discussion}

The aim of the present investigation was to study the effect of feeding high sucrose diet on plasma lipid profile, plasma antioxidant activity, antioxidant enzymes in RBC hemolysate general health conditions of rats and also attempted to study the effect of syrup of peaches and pears (peel and pulp) \& green tea on the restoration of the changes produced by feeding high sucrose diet. Previous studies indicated that sucrose is lipogenic and induced hyperlipidemia [38]. Sucrose in the present study was found to induce hyperlipidemia as there was a significant $(\mathrm{P} \leq 0.05)$ increase in the levels of cholesterol, TG and LDL, liver enzymes (ALT, AST) in plasma and in the TG levels in the hearts of rats that received sucrose only without supplementation. Administration of sucrose in the diet also resulted in elevation of lipid Peroxides (MDA) and reduction in the activities of SOD, GSH-Px, CAT and a decrease in the concentration of the natural antioxidant reduced glutathione in plasma Also administration of sucrose resulted in histopathological changes in heart tissues that may be mainly due to liberation of lipid peroxides (MDA). MDA is a secondary product of lipid peroxidation and is known to cause damage to the cell by making cross linkage of membrane components containing amino groups and make the membrane fragile [47]. However, administration of fruits syrup and green tea resulted in a significant reduction in the elevated levels of cholesterol, TG and LDL and TG in the heart. Green tea produced the best lowering effect and restored all other affected parameters to almost normal values. Green tea is non-fermented tea. It contains catechinepicatechin, epicatechin gallate, epigallocatechin, and epigallocatechingallate [23]. It was reported that green tea reduced hyperlipidemia and reduced fat storage in the heart of rats that received high sucrose diet .This was achieved by the finding that green tea prevented or reduced the absorption of fat [29].

Results obtained in the present study confirmed the previous results of Kono, et al. [27] and Stensvold et al. [28], who reported that consumption of green tea inversely correlated with plasma cholesterol concentrations. For all these reasons green tea may modulate lipid metabolism and that may be through regulation of lipid absorption and/or enhancing antioxidant status as can be seen in Table 4. There was an increase in the level of 

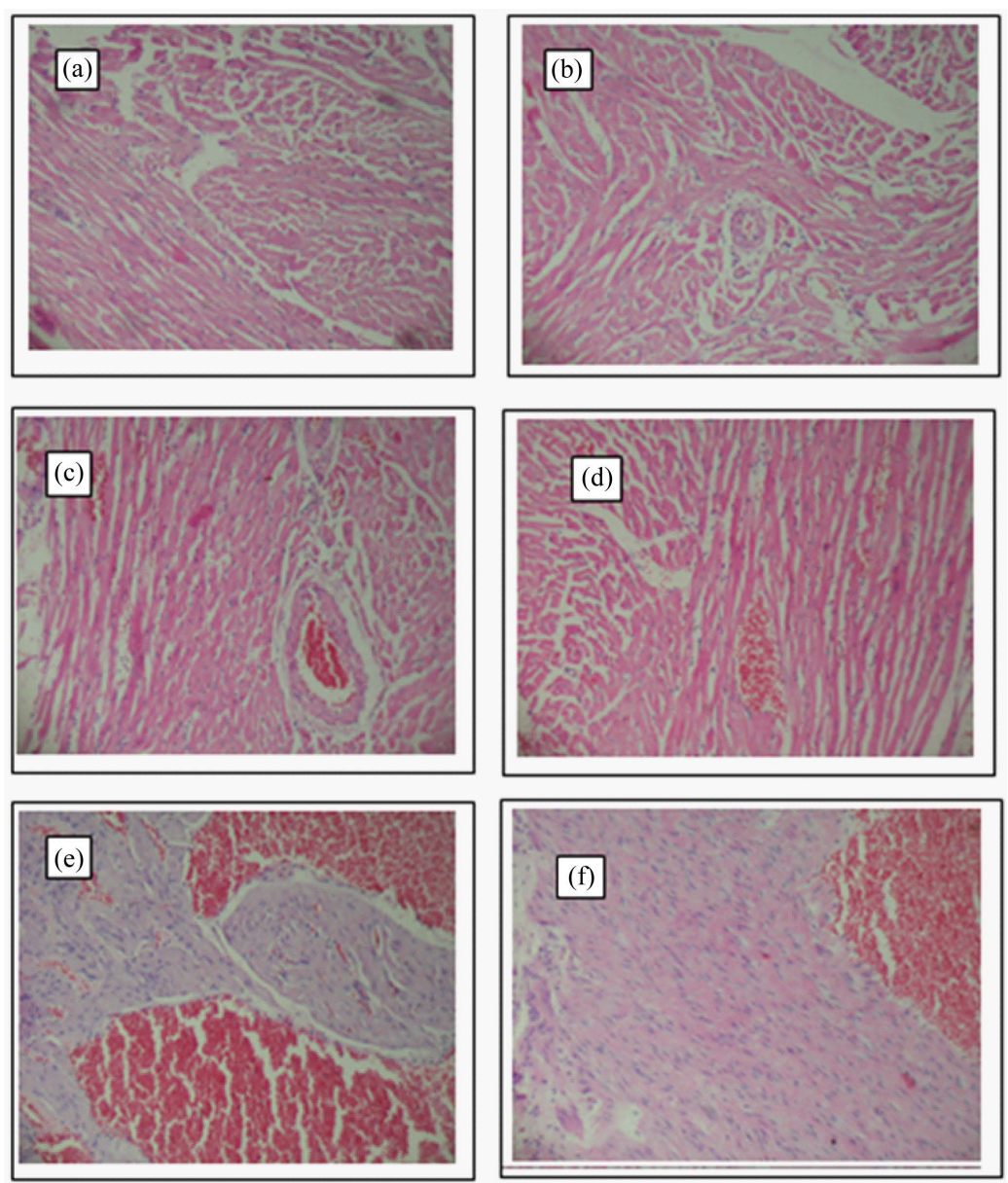

Figure 2. Pathological changes in heart tissues following intake of high sucrose diet and treatments with fruit extracts $(\mathrm{H} \& \mathrm{E} \times 200)$.

Table 6. Pathological changes in the different groups.

\begin{tabular}{|c|c|}
\hline Groups & Pathological changes \\
\hline Negative control & showing normal architecture of the cardiac muscle fibers with small rounded central nuclei. (Figure 2(a)) \\
\hline Positive control & $\begin{array}{l}\text { showing marked separation of cardiac muscle fibers with diffuse haemorrhage and congestion in the cardiac muscle } \\
\text { fibers. (Figure 2(e)) }\end{array}$ \\
\hline pulp of peaches & Myocardium, showing moderate haemorrhage in the cardiac muscle fibres. (Figure 2(f)) \\
\hline Peel of peaches & Mild separation of cardiac muscle fibers with mild haemorrhage and congestion blood vessels. (Figure 2(d)) \\
\hline pulp of Pears & Showing mild separation of cardiac muscle fibers with mild haemorrhage and congestion blood vessels. (Figure 2(c)) \\
\hline Peel of pears & (spoiled) \\
\hline Green tea & $\begin{array}{l}\text { Showing normal architecture of the cardiac muscle fibers mild haemorrhage and fibrosis. Some nuclei are degenerated } \\
\text { and other are PyKontic. (Figure 2(b)) }\end{array}$ \\
\hline
\end{tabular}

TAS and GSH and an increase in the HDL and a decrease in the concentration of LDL (Table 3). The increase in the level of reduced glutathione is important because GSH is the most important non-protein thiol (-SH) in living organisms and perform a central role in coordinating the body's antioxidant defense process. It is involved in the maintenance of normal cell structure and function, probably through its redox and detoxification reactions. GSH levels were lowered in rats that received sucrose without fruits and green tea, and they were near to normal 
on treatment with fruits and green tea. Another important finding in the present study was the increase in the concentration of malondialdehyde (MDA). Results in the present study showed a significant increase $(\mathrm{P}<0.05)$ in MDA level $(14.81 \pm 0.48 \mu \mathrm{mol} / \mathrm{l})$ in rats that received sucrose only compared to $5.06 \pm 0.18 \mu \mathrm{mol} / \mathrm{l}$ in the normal control group. MDA is a secondary product of lipid peroxidation and is known to cause damage to the cell by making crosslinkage of membrane components containing amino groups and make the membrane fragile [47]. Fruit and vegetables have long been known for their health benefits and in preventing various prevailing diseases such as cancers and age-related diseases [48]. It was reported in previous studies that pears, peaches and apples are rich sources of poly phenols, phenolic acids, caffeic, p-coumaric, ferulic acids and TRAP value (total antioxidant capacity [49]. Marcia et al. [50] found that total phenolic content are very high in these fruits and had high antioxidant activity. The presence of such compounds may explain the beneficial effect of these fruits against most ill effects produced by feeding high sucrose as exemplified by hyperlipidemia such as hypercholesterolemia, triglyceridemia. Pears and peaches (peel \&pulp) are found to be beneficial. Pears are found to be superior to peaches in this respect. This may be explained by the fact that the total phenolic contents were found to be $228.5 \pm 0.74 \mathrm{mg}$ gallic acid equivalents $/ 100 \mathrm{~g}$ fresh weight of pears fruit juice. Pears were found to contain many other bioactive substances such as total flavonoids, carotenoids, betalains, total, soluble, insoluble dietary fibers and taurine [51]. In both pears and peaches, peels were found to be more effective in restoring lipid profile when compared with the pulps of these fruits. This is in agreement with the findings of Gorinstein et al. [52] and Bocco et al. [53], that Peels of fruits is one of the major sources of natural antioxidants Some authors even proposed to use the by-products of juice extraction industry as natural source of dietary fiber and antioxidants [53]. Generally Fruits are considered to have antioxidant, hypoglycemic, hypocholesterolemic and antiatherogenic properties due to their positive effects on the redox balance, prevent oxidative damage, lipid peroxidation and improve antioxidant status in consumers.

\section{Conclusion}

It can be concluded from the present study that feeding syrup of pears and peaches (pulp \& peel) and green tea increased the antioxidant capacity and can scavenge reactive oxygen species which resulted in reduced Hypercholesterolemia, hypertriglyceridemia, lipid peroxidation (MDA), improved the activities of antioxidant enzymes (SOD, GSH-Px) and Catalase and blood reduced glutathione and plasma aminotransferases (ALT, AST) and plasma urea. Moreover, histopathological examination of the heart tissue showed signs of recovery from separation of cardiac muscle fibers, diffuse haemorrhage and congestion. Thus it can be concluded that administration of pears, peaches and green tea can protect from oxidative stress generated by feeding high sucrose diet and in this respect green tea produced the higher improvement followed by peels of pears and peaches.

\section{References}

[1] Rekhy, R. and McConchie, R. (2014) Promoting Consumption of Fruit and Vegetables for Better Health. Have Campaigns Delivered on the Goals. Appetite, 79, 113-123. http://dx.doi.org/10.1016/j.appet.2014.04.012

[2] Glasson, C., Chapman, K. and James, E. (2011) Fruit and Vegetables Should Be Targeted Separately in Health Promotion Programmes: Differences in Consumption Levels Barriers, Knowledge and Stages of Readiness for Change. Public Health Nutrition, 14, 694-701. http://dx.doi.org/10.1017/S1368980010001643

[3] Halicka, E. and Rejman, K. (2007) Fruit and Vegetable Promotion Programs in the European Union. Problems of World Agriculture. Warsaw University of Life Sciences Press, Warsaw.

[4] He, F.J., Nowson, C.A. and MacGregor, G.A. (2006) Fruit and Vegetable Consumption and Stroke: Meta-Analysis of Cohort Studies. The Lancet, 367, 320-326. http://dx.doi.org/10.1016/S0140-6736(06)68069-0

[5] He, F.J., Nowson, C.A., Lucas, M. and MacGregor, G.A. (2007) Increased Consumption of Fruit and Vegetables Is Related to a Reduced Risk of Coronary Heart Disease: Meta-Analysis of Cohort Studies. Journal of Human Hypertension, 21, 717-728. http://dx.doi.org/10.1038/sj.jhh.1002212

[6] Ortega, R.M. (2006) Importance of Functional Foods in the Mediterranean Diet. Public Health Nutrition, 9, 1136-1140. http://dx.doi.org/10.1017/s1368980007668530

[7] Radhika, G., Sudha, V., Mohan Sathya, R., Ganesan, A. and Mohan, V. (2008) Association of Fruit and Vegetable Intake with Cardiovascular Risk Factors in Urban South Indians. The British Journal of Nutrition, 99, 398-405. http://dx.doi.org/10.1017/S0007114507803965

[8] World Health Organization (2000) Obesity: Preventing and Managing the Global Epidemic: Report of a WHO Con- 
sultation. WHO Technical Report Series 894, World Health Organization, Geneva.

[9] Wang, S., Melnyk, J.P., Tsao, R. and Marcone, M.F. (2011) How Natural Dietary Antioxidants in Fruits, Vegetables and Legumes Promote Vascular Health. Food Research International, 44, 14-22. http://dx.doi.org/10.1016/j.foodres.2010.09.028

[10] Dauchet, L., Amouyet, P. and Dallongeville, J. (2005) Fruit and Vegetable Consumption and Risk of Stroke. A MetaAnalysis of Cohort Studies. Neurology, 65, 1193-1197. http://dx.doi.org/10.1212/01.wnl.0000180600.09719.53

[11] Hu, F.B. (2003) Plant-Based Foods and Prevention of Cardiovascular Disease: An Overview. The American Journal of Clinical Nutrition, 78, 544S-551S.

[12] Ness, A.R. and Powles, J.W. (1997) Fruit and Vegetables, and Cardiovascular Disease: A Review. International Journal of Epidemiology, 26, 1-13. http://dx.doi.org/10.1093/ije/26.1.1

[13] Nothlings, U., Schulze, M.B., Weikert, C., Boeing, H., van der Schouw, Y.T. and Bamia, C. (2008) Intake of Vegetables, Legumes, and Fruit, and Risk for All-Cause Cardiovascular, and Cancer Mortality in a European Diabetic Population. The Journal of Nutrition, 138, 775-781.

[14] Al-Nuaim, A. (1997) Effect of Overweight and Obesity on Glucose Intolerance and Dyslipidemia in Saudi Arabia, Epidemiological Study. Diabetes Research and Clinical Practice, 36, 181-191. http://dx.doi.org/10.1016/S0168-8227(97)00041-7

[15] Al Balla, S., Bamgboye, E.A., Al Balla, S.R., Al Sekait, M. and Al Rasheed, R. (1993) Pattern of Adult Admission into Medical Wards of King Khalid University Hospital, Riyadh (1985-1990). Saudi Medical Journal, 13, 8-13.

[16] Al Balla, S.R., Bamgboye, E.A., Sekait, M. and Balla, M. (1993) Causes of Morbidity in the Elderly Population of Saudi Arabia. The Journal of Tropical Medicine and Hygiene, 96, 157-162.

[17] Al-Nuaim, A.R., AlRubeaan, K.A. and AlMazrou, Y. (1996) High Prevalence of Overweight and Obesity in Saudi Arabia. International Journal of Obesity, 20, 547-552.

[18] Cullen, P. (2000) Evidence that Triglycerides Are an Independent Coronary Heart Disease Risk Factor. American Journal of Cardiology, 9, 86-943. http://dx.doi.org/10.1016/s0002-9149(00)01127-9

[19] Haim, M., Benderly, M., Brunner, D., Behar, S., Graff, E., Reicher-Reiss, H. and Goldbourt, U. (1999) Elevated Serum Triglyceride Levels and Long-Term Mortality in Patients with Coronary Heart Disease. Circulation, 100, 475-482. http://dx.doi.org/10.1161/01.CIR.100.5.475

[20] JBR (1998) Joint British Recommendations on Prevention of Coronary Heart Disease in Clinical Practice. Heart, 80, S1-S29.

[21] Graham, H.N. (1992) Green Tea Composition, Consumption, and Polyphenol Chemistry. Preventive Medicine, 21, 334-350.

[22] Sabu, M.C., Smitha, K. and Kuttan, R. (2002) Anti-Diabetic Activity of Green Tea Polyphenols and Their Role in Reducing Oxidative Stress in Experimental Diabetes. Journal of Ethnopharmacology, 83, 109-116.

[23] Lin, J.-K., Lin, C.-L., Liang, Y.-C., Lin-Shiau, S.-Y. and Juan, I.-M. (1998) Survey of Catechins, Gallic Acid, and Methylxanthines in Green, Oolong Pu-erh, and Black Tea. Journal of Agricultural and Food Chemistry, 46, 3635-3642. http://dx.doi.org/10.1021/jf980223x

[24] Lee, M-H., Chen, S.-C. and Min, B.-W. (1989) Effects of Extraction Method on the Determination of Tea Tannin and Catechins. Journal of Chinese Agricultural Chemistry, 27, 82-88.

[25] Almajano, M.P., Carbo, R., Jiménez, J. and Gordon, M.H. (2008) Antioxidant and Antimicrobial Activities of Tea Infusions. Food Chemistry, 108, 55-63. http://dx.doi.org/10.1016/j.foodchem.2007.10.040

[26] Weber, J.M., Ruzindana-Umunyana, A., Imbeault, L. and Sircar, S. (2003) Inhibition of Adenovirus Infection and Adenain by Green Tea Catechins. Antiviral Research, 58, 167-173. http://dx.doi.org/10.1016/S0166-3542(02)00212-7

[27] Kono, S., Shinchi, K., Ikeda, N., Yanai, F. and Imanishi, K. (1992) Green Tea Consumption and Serum Lipid Profiles: A Cross-Sectional Study in Northern Kyushu, Japan. Preventive Medicine, 21, 526-531. http://dx.doi.org/10.1016/0091-7435(92)90060-U

[28] Stensvold, I., Tverdal, A., Solvoll, K. and Foss, O.P. (1992) Tea Consumption Relationship to Cholesterol, Blood Pressure, and Coronary and Total Mortality. Preventive Medicine, 4, 546-553.

[29] Muramatsu, K., Fukuyo, M. and Jara, Y. (1986) Effect of Green Tea Catechins on Plasma Cholesterol Level in Cholesterol-Fed Rats. Journal of Nutritional Science and Vitaminology, 32, 622-613. http://dx.doi.org/10.3177/jnsv.32.613

[30] Kim, M.K., Cho, S.W. and Park, Y.K. (2007) Long-Term Vegetarians Have Low Oxidative Stress, Body Fat, and Cholesterol levels. Nutrition Research and Practice, 6, 155-161. http://dx.doi.org/10.4162/nrp.2012.6.2.155

[31] Raja, M., Hernández-Revelles, J., Hernández-Cassou, S. and Saurina, J. (2014) Deter Mination of Polyphenols in the Pear Pulp Matrix by Solvent Extraction and Liquid Chromatography with UV-Vis Detection. Analytical Methods, 24, 
9769-9776. http://dx.doi.org/10.1039/C4AY02558J

[32] Amiot, M.J., Tacchini, M., Aubert, S.Y. and Oleszek, W. (1995) Influence of Cultivar, Maturity Stage, and Storage Conditions on Phenolic Composition and Enzymic Browning of Pear Fruits. Journal of Agricultural and Food Chemistry, 43, 1132-1137. http://dx.doi.org/10.1021/jf00053a004

[33] Lin, L.Z. and Harnly, J.M. (2008) Phenolic Compounds and Chromatographic Profiles of Pear Skins (Pyrus spp.). Journal of Agricultural and Food Chemistry, 56, 9094-9101. http://dx.doi.org/10.1021/jf8013487

[34] Subedi, P.P. and Walsh, K.B. (2009) Non-Invasive Techniques for Measurement of Fresh Fruit Firmness. Postharvest Biology and Technology, 51, 297-304. http://dx.doi.org/10.1016/j.postharvbio.2008.03.004

[35] Tomás-Barberán, F.A., Gil, M.I., Cremin, P., Waterhouse, A.L., Hess-Pierce, B. and Kader, A.A. (2001) HPLCDAD-ESIMS Analysis of Phenolic Compounds in Nectarines Peaches, and Plums. Journal of Agricultural and Food Chemistry, 49, 4748-4760. http://dx.doi.org/10.1021/jf0104681

[36] Caballero, B. (2013) Sucrose: Dietary Sucrose and Disease. In: Caballero, B., Ed., Encyclopedia of Human Nutrition 3rd Edition, Elsvier, Amsterdam, 231-233. http://dx.doi.org/10.1016/B978-0-12-375083-9.00257-9

[37] Lombardo, Y.B., Chicco, A., Mocchiuttti, N., de Rodi, M.A., Nusinmovich, B. and Gutman, R. (1983) Effect of Sucrose Diet on Insulin Secretion in Vivo and in Vitro and on Triglyceride Storage and Mobilization of the Heart of Rats. Hormone and Metabolic Research, 15, 69-76.

[38] Lombardo, Y.B., Drago, S., Chicco, A., Fainstein-Day, P., Gutman, R., Gagliardino, J.J. and Gomez Dumm, C.L. (1996) Long-Term Administration of a Sucrose-Rich Diet to Normal Rats: Relationship Between Metabolic and Hormonal Profiles and Morphological Changes in the Endocrine Pancreas. Metabolism, 45, 1527-1532. http://dx.doi.org/10.1016/S0026-0495(96)90183-3

[39] Rovenko, B.M., Kubrak, O.I., Gospodaryov, D.V., Perkhulyn, N.V., Yurkevych, I.S., Sanz, A., Lushchak, O.V. and Lushchak, V.I. (2015) High Sucrose Consumption Promotes Obesity whereas Its Low Consumption Induces Oxidative Stress in Drosophila Melanogaster. Journal of Insect Physiology, 79, 42-54. http://dx.doi.org/10.1016/j.jinsphys.2015.05.007

[40] Lukaszewicz-Hussain, A. and Moniuszko-Jakoniuk, J. (2004) Liver Catalase, Glutathione Peroxidase and Reductase Activity, Reduced Glutathione and Hydrogen Peroxide Levels in Acute Intoxication with Chlorfenvinphos, an Organophosphate Insecticide. Polish Journal of Environmental Studies, 13, 303-309.

[41] Reitman, S. and Frankel, S. (1957) A Colorimetric Method for Determination of Serum Glutamic Oxalacetic and Glutamic Pyruvic Transaminase. American Journal of Clinical Pathology, 28, 56-63.

[42] Bradford, M.A. (1976) A Rapid and Sensitive Method for the Quantitation of Microgram Quantities of Protein Utilizing the Principle of Protein-Dye Binding. Analytical Biochemistry, 72, 248-256. http://dx.doi.org/10.1016/0003-2697(76)90527-3

[43] Tietz, N.W. (1987) Fundamentals of Clincial Chemistry. 3rd Edition, W.B. Saunders, Philadelphia.

[44] Davidson, I. and Henry, J.B. (1974) Clinical Diagnosis by Laboratory Methods. 15th Edition, W.B. Saunders, Philadelphia.

[45] Grillo, F., Izzo, C., Mazzotti, G. and Murador, E. (1981) Improved Method for Determination of High-Density-Lipoprotein Cholesterol II. Enzymic Determination of Cholesterol in High-Density Lipoprotein Fractions with a Sensitive Reagent. Clinical Chemistry, 27, 375-379.

[46] Folch, J., Lees, M. and Sloane Stanley, G.H. (1957) A Simple Method for the Isolation and Purification of Total Lipides from Animal Tissues. The Journal of Biological Chemistry, 226, 497-509.

[47] Cameron, N.E. and Cotter, M.A. (1994) The Relationship of Vascular Changes to Metabolic Factors in Diabetes Mellitus and Their Role in the Development of Peripheral Nerve Complications. Diabetes/Metabolism Reviews, 10, 189-224. http://dx.doi.org/10.1002/dmr.5610100302

[48] Prior, R.L. and Cao, G. (2000) Antioxidant Phytochemicals in Fruits and Vegetables: Diet and Health Implications. HortScience, 35, 588-592.

[49] Belitz, H.-D. and Grosch, W. (1999) Fruits and Fruit Products. In: Belitz, H.-D. and Grosch, W., Eds., Food Chemistry, Chap. 18, Springer, New York, 748-799. http://dx.doi.org/10.1007/978-3-662-07281-3_19

[50] Vizzotto, M., Cisneros-Zevallos, L. and Byrne, D.H. (2007) Large Variation Found in the Phytochemical and Antioxidant Activity of Peach and Plum Germplasm. Journal of the American Society for Horticultural Science, 132, $334-340$.

[51] El-Razek, F.H.A. and Hassan, A.A. (2011) Nutritional Value and Hypoglycemic Effect of Prickly Cactus Pear (Opuntia ficus-indica) Fruit Juice in Alloxan-Induced Diabetic Rats. Australian Journal of Basic and Applied Sciences, 5, 356-377.

[52] Gorinstein, S., Kulasek, G., Bartnikowska, E., Leontowicz, M., Morawiec, M., Zemser, M. and Trakhtenberg, S. (1998) The Influence of Persimmon Peel and Persimmon Pulp on the Lipid Metabolism and Antioxidant Activity of Rats Fed 
Cholesterol. The Journal of Nutritional Biochemistry, 9, 223-227. http://dx.doi.org/10.1016/S0955-2863(98)00003-5

[53] Bocco, A., Cuvelier, M.E., Richard, H. and Berset, C. (1998) Antioxidant Activity and Phenolic Composition of Citrus Peel and Seed Extracts. Journal of Agricultural and Food Chemistry, 46, 2123-2129. http://dx.doi.org/10.1021/jf9709562 